\title{
Effect of Planting Media on the Germination and Early Growth of Dacryodes Edulis (G. Don) H. J. Lam
}

\author{
Amonum, J.I., NIAMBE, O.K., Japheth H.D \\ Department of Forest Production and Products, College of Forestry and Fisheries, University of Agriculture \\ Makurdi-Nigeria
}

*Corresponding Authors: Amonum, J.I., Department of Forest Production and Products, College of Forestry and Fisheries, University of Agriculture Makurdi, Nigeria

\begin{abstract}
Dacryodes edulis (G Don) is an evergreen tree attaining a height of 18-40 $\mathrm{m}$ in the forest but not exceeding $12 \mathrm{~m}$ in plantations. In Nigeria, it is an important food supplement. The species is a delicacy among the people in several parts of Nigeria where it is consumed in association with other foods such as fresh maize. It is a highly nutritious fruit. Lack of knowledge, especially in propagation techniques for this woody species, inhibits farmers in Africa, including Nigeria, from successfully growing this multipurpose forest fruit tree species. A study was conducted to determine the germination and seedling growth of Dacryodes edulis (African pear) as affected by different planting media: top garden soil, river sand, sawdust and a mixture of river sand and sawdust. Sawdust and river sand was mixed in a ratio of 50:50 in the Forestry Nursery of Federal University of Agriculture Makurdi. Seeds were procured and sown in the poly pots filled with various sowing media of sawdust river sand, top soil, and composite mixture of sawdust and river sand. The experiment was laid out in a Completely Randomized Design (CRD) with 3 replicates. The results showed seeds planted in River sand had the highest germination of $100 \%$ and was significantly different $(p \leq 0.05)$ from those sown in other growth media (river sand and river sand combined with sawdust had $96.67 \%$ each while topsoil had $80 \%$ ). The results also indicated that the performance of the seedlings in terms of height, number of leaves, leaf area and collar diameter planted in the composite mixture of Sawdust and River was better though not significantly different $(p>0.05)$ compared to those in the other growth media except for Top soil medium that had relatively low performance. This study has established that the germination and seedling growth of $D$. edulis are significantly affected by planting media; while river sand recorded better growth performance and is therefore recommended for raising seedlings for plantation establishment.
\end{abstract}

Keywords: D. edulis, Germination, Growth medium, Plantation, Seedlings.

\section{INTRODUCTION}

Dacryodes edulis (G Don) is a multipurpose plant in Nigeria and Africa at large (Zofou et al., 2013); which grows in the humid tropics. Many households and communities depend on this multipurpose tree for the provision of goods and services that include edible fruits, herbal medicines or fuel wood as well as global service by facilitating carbon sequestration with the potential for climate change mitigation (Albrecht and Kandji, 2003). The gathering of the fruits of D. edulis serves as a veritable source of employment and income for rural populace (Agbogidi et al., 2007).

In Nigeria, it is an important food supplement. D. edulis is a delicacy among the people in several parts of Nigeria where it is consumed in association with other foods such as fresh maize (Agbogidi and Eshegbeyi, 2006). It is a highly nutritious fruit whose edible pulp contains ash (10.8\%), fibre $(17.9 \%)$, oil (31.9\%), protein $(25.9 \%)$, energy $(444.7 \mathrm{kcal} / 100 \mathrm{~g})$, carbohydrate $(13.5 \%)$ and moisture content (12.04\%) (Agbogidi et al, 2007).

Lack of information on propagation techniques for the woody species inhibits farmers from successfully growing this multipurpose forest fruit tree species (Schreckenberg et al. 2002; Akinnifesi et al. 2008). Due to inadequate research on planting and regeneration of economic woody species in Africa; and most of the work to date has been skewed towards exotic tree species. Consequently, there is an urgent need to study and improve both new and existing methods for propagation and regeneration of the tree species (Nyamukuru et al., 2014). 
With increasing population pressure and high demand for this multipurpose forest fruit tree and consequent on the fact that very few farmers domesticate and cultivate D. edulisi in Nigeria, due to the limited information on the germination of the seeds as well as the seasonality of fruit production and inability of the fruits to store well for a long period of time, the need to develop the best planting medium required for the germination and early seedling growth of $D$. edulis cannot be over emphasized (Agbogidi et al., 2007). D. edulis has also been included in the list of endangered forest species (Leakey, 1999; Nwoboshi, 2000). This calls for urgent attempt to domesticate and enhance their acceptability to local farmers, to ensure that the future generation is not deprived of the inherent benefits of this economically important fruit tree species.

The use of suitable growing medium is essential for production of quality plant seedlings. It directly affects the growth, development and maintenance of the functional rooting system. A good growing medium would provide sufficient support to plant; it would also serves as reservoir for nutrients and water, allow oxygen diffusion to the roots and permit gaseous exchange between the roots and atmosphere outside the root substrate (Abad et al., 2002). Nursery potting media influence quality of seedlings produced (Agbo and Omaliko, 2006). The quality of seedling obtained from a nursery influences re-establishment in the field and the eventual productivity of an orchard (Baiyeri, 2006). Thus the aim for this study is to evaluate various planting media to ascertain the most suitable medium for the germination and early seedling growth of $D$. edulis so as to enhance its success in propagation and cultivation in the study area.

\section{MATERIALS AND METHODS}

\subsection{The Study Area}

This study was conducted at the Forestry Nursery of the Department of Forestry, Wildlife and Range Management, University of Agriculture Makurdi, Nigeria. The Forestry Nursery lies between Longitude $8^{\circ} 21^{\prime}$ and $9^{\circ} \mathrm{E}$ and Latitude $7^{\circ} 21^{\prime}$ and $8^{\circ} \mathrm{N}$ within the southern guinea savanna ecological zone. The climate of the area is tropical sub-humid with high temperatures and high humidity. The maximum temperature is $350 \mathrm{C}$ while the minimum temperature is $230 \mathrm{C}$ (Seibert, 2007). The climate is characterized by two distinct seasons namely; rainy and dry seasons with an annual rainfall of $1200 \mathrm{~mm}-1500 \mathrm{~mm}$. The vegetation of the area has been described as Southern guinea savanna. The major occupations of the people include; farming, fishing, trading and hunting; the major tribes are Tiv, Idoma and Igede.

\subsection{Seed Procurement and Extraction}

Fruits of Dacryodes edulis were purchased from railway market in Makurdi, Benue state in Nigeria. This market is a well-known market of D. edulis and other fruits. This became necessary due to the recalcitrant nature of the seeds and the seasonality in seed production of the tree species (Agbogidi et al., 2007). Viable seeds were sorted out by simple flotation techniques following the procedure of Agbogidi and Eshegbeyi (2006). Seeds are recalcitrant and thus could not be stored for a long time. It loses its viability when subjected to drying or freezing (Walters et al., 2013). Seeds were extracted from the mature fruits of Dacryodes edulis in which the fruits were mechanically de-pulped to expose the seeds using a blade. The fruits were split open and deseeded carefully to avoid affecting the anatomical structure of the seed.

\subsection{Seed Sowing and Filling of Polythene Pot}

Bottom perforated polythene pots were filled with various planting media of top soil (TS), river sand (RS), saw dust (SD) and a mixture of sawdust and river sand (SR); the mixture of river sand and sawdust was done in the ratio 1:1. The extracted seeds of Dacryodes edulis were planted directly into the poly pots and each filled with the planting media of top soil (TS), river sand (RS), saw dust (SD) and a mixture of sawdust and river sand (TR), respectively. Watering of the sown seed was done consistently every day after planting to give the seed every condition needed for proper growth.

\subsection{Experimental Design}

The experiment was laid out in Completely Randomized Design (CRD) at the Forestry nursery in the study area. The study involved the use of four (4) planting media and three (3) replicates. The treatments were: river sand, top soil, sawdust and composite mixture of sawdust and river sand. Total of 120 seeds were planted for the study. This study was observed for the duration of eight (8) weeks while variables were measured forth nightly starting from the 2 ndweek after planting. 


\subsection{Data Collection and Analysis}

Daily observations were made to determine the effects of the four planting media on the germination of seeds of D. edulis. Germination of seeds were discontinued and considered to have been completed when no additional germination took place in two weeks. Data on growth variables were measured; these include: seedling heights were measured from the collar region to the tip of the seedlings by the use of meter rule. Collar diameters were measured using a veneer caliper. Number of leaves was determined by manual counting on the seedlings. Leaf area was measured by tracing three (3) leaves of seedling on a graduated graph sheet. Five seedlings from each treatment were sampled and leaf area assessed fortnightly (Aluko et al., 2014). The growth variables were measured in every two (2) weeks interval for a period of eight (8) weeks.

Data collected on seed germination and growth rate (seedling heights, number of leaves, collar diameter and leaf area) were subjected to descriptive statistics (percentages, mean and standard deviation) and inferential statistics (one-way analysis of variance (ANOVA)) were used to analyze data collected in the study area. Where significant differences occurred between the treatments means, the least significant difference (LSD) method was used to separate the means (William et al., 2012; Imoro et al., 2012; Aluko et al., 2014).

\section{RESULTS}

The results of these finding on germination rate is presented in Figure 1. There was no germination observed within the first 9 days after the seeds of D. edulis were planted in the study area. Germination and emergence of D. edulis seeds commenced on the 10thday; top soil had the lowest germination percentage of $45 \%$ and composite mixture of sawdust and river sand had the highest germination rate of $82 \%$. There was increase on seeds germination on the 12th day after seeds planting. On the 14th day, river sand planting medium had the highest (100\%) level of germination rate as observed. This was followed by sawdust growth medium and composite medium of sawdust and river sand which both had $98 \%$ germination on the 14 th day. The lowest germination percent was recorded from the top soil planting medium with $80 \%$ on the 14 th day.

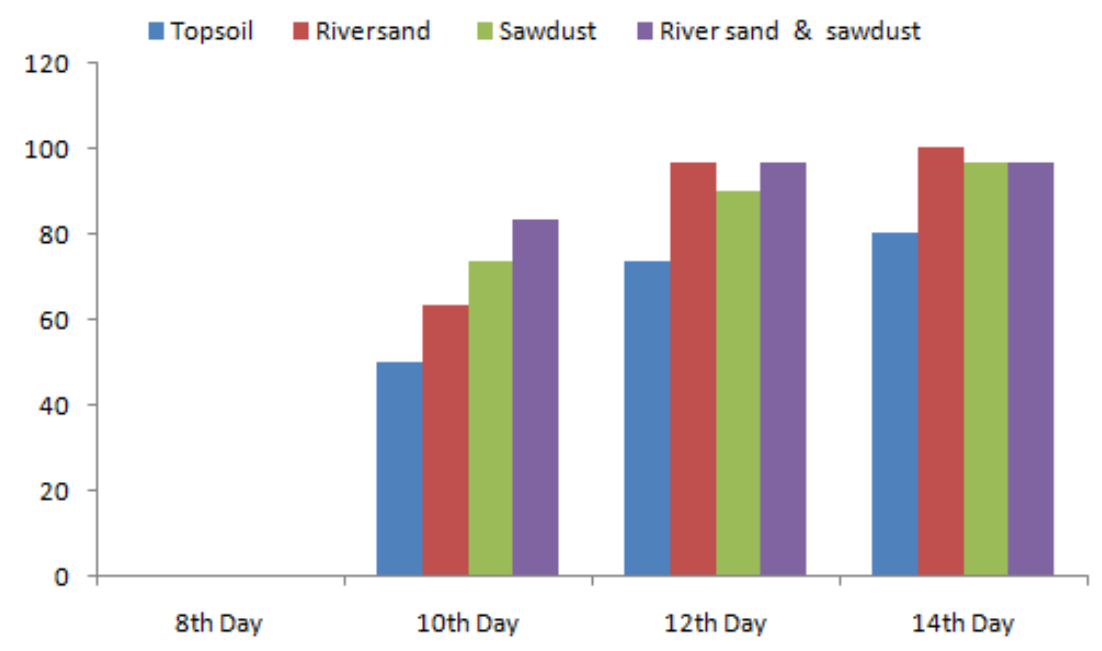

Figure1. Effects of Different Planting Media on Germination Rate of Dacryodes edulis Seeds in the Study Area The effect of planting media on the seedlings of D. edulis is presented on Figure 2. Top soil growth medium had the lowest mean leaf number of 5.14; river sand had mean leaf number of 7.09, sawdust (7.74) and river sand mixed with sawdust had 7.47 mean number of leaves recorded. Seedlings height of D. edulis showed river sand mixed with sawdust as had $19.43 \mathrm{~cm}$ mean height recorded, followed by sawdust $(18.40 \mathrm{~cm})$, river sand had a mean height of $18.21 \mathrm{~cm}$ while top soil growth medium had the lowest mean seedling height of $14.01 \mathrm{~cm}$. D. edulis seedlings girth was assessed, and sawdust had $0.48 \mathrm{~cm}$ with the highest seedling girth, followed by river sand and river sand mixed with sawdust 0.7 $\mathrm{cm}$ each while top soil had the lowest mean seedling girth of $0.41 \mathrm{~cm}$ (Figure 2).

The leaf area of D. edulis seedlings was assessed based on planting media; river sand had the highest mean leaf area of $38.64 \mathrm{~cm} 2$, followed by river sand; and sawdust $(33.13 \mathrm{~cm} 2)$, top soil $(29.57 \mathrm{~cm} 2)$ while saw dust had the lowest mean leaf area of $27.6 \mathrm{~cm} 2$ (Figure 3). 


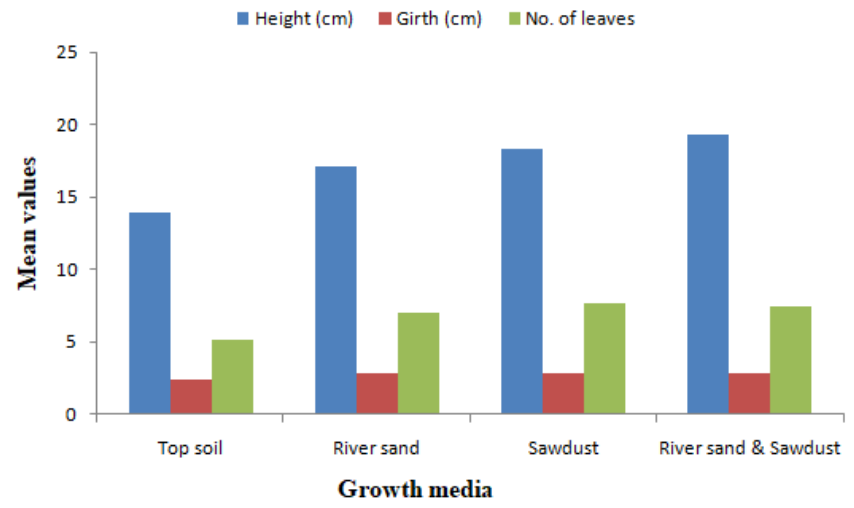

Figure2. Effects of Planting Media on the Mean Height (cm), Girth (cm) and Number of leaves in the Study Area

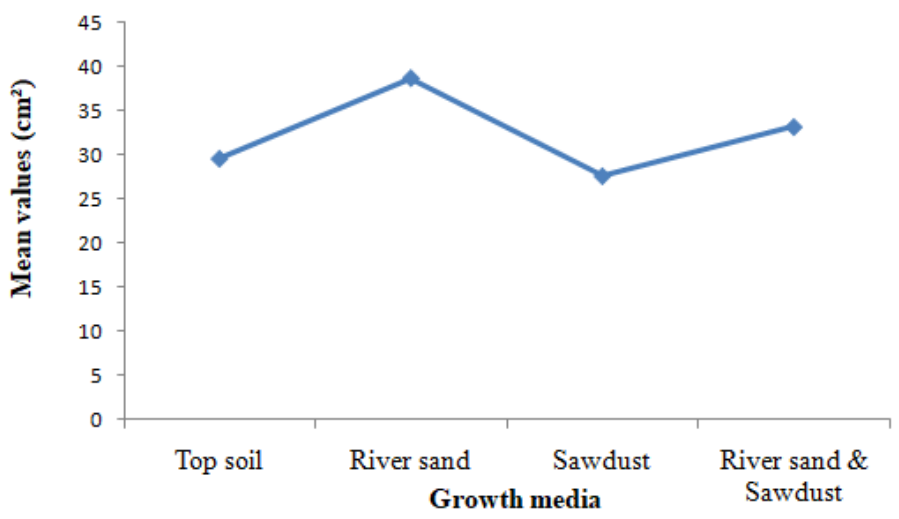

Figure3. Effects of Planting Media on the Mean Leaf Area $\left(\mathrm{cm}^{2}\right)$ in the Study Area

Table 1 shows the results on the effect of planting media on the growth variables of D. edulis seedlings. Based on the result, there was significant difference $(p<0.05)$ on the growth variables from different growing media in the study area. Number of leaves had a significant difference of $p=0.001$, seedlings height and leaf area which was significantly different $(\mathrm{p}=0.001)$ while seedlings girth had $\mathrm{p}=0.002$.

Table1. ANOVA Result on the Comparative Effects of Different Planting Media on Dacryodes Edulis Seedlings In The Study Area

\begin{tabular}{|l|l|l|l|l|}
\hline \multirow{2}{*}{ Planting media } & \multicolumn{4}{|c|}{ Variables } \\
\cline { 2 - 5 } & No. of leaves & Height $(\mathbf{c m})$ & Girth $(\mathbf{c m})$ & Leaf area $\left(\mathbf{c m}^{\mathbf{2}}\right)$ \\
\hline Top soil & $5.14 \pm 4.17^{\mathrm{b}}$ & $14.01 \pm 4.06^{\mathrm{c}}$ & $0.41 \pm 0.23^{\mathrm{b}}$ & $29.57 \pm 9.58^{\mathrm{bc}}$ \\
\hline River sand & $7.09 \pm 3.82^{\mathrm{a}}$ & $17.21 \pm 8.63^{\mathrm{b}}$ & $0.47 \pm 0.13^{\mathrm{a}}$ & $38.64 \pm 8.93^{\mathrm{a}}$ \\
\hline Sawdust & $7.74 \pm 4.06^{\mathrm{a}}$ & $18.40 \pm 5.60^{\mathrm{a}}$ & $0.48 \pm 0.14^{\mathrm{a}}$ & $27.60 \pm 6.64^{\mathrm{c}}$ \\
\hline River sand \& Sawdust & $7.47 \pm 3.72^{\mathrm{a}}$ & $19.43 \pm 6.35^{\mathrm{a}}$ & $0.47 \pm 0.12^{\mathrm{a}}$ & $33.13 \pm 9.56^{\mathrm{b}}$ \\
\hline P-value & $<\mathbf{0 . 0 0 0}$ & $<\mathbf{0 . 0 0 0}$ & $\mathbf{0 . 0 0 2}$ & $<\mathbf{0 . 0 0 0}$ \\
\hline
\end{tabular}

Means on the same column with different superscripts are statistically significant $(p<0.05)$

\section{DISCUSSION}

\subsection{Effect of Planting Media on Germination Rate of $D$. Edulis}

This finding showed that the overall germination rate was best recorded under river sand planting medium. This implied that the preferred germination medium for D. edulis was river sand in the study area. This could be as a result of high porosity of river sand compare to topsoil and sawdust; as reported by Purwantoro (2016), "the porosity of river sand medium allows imbibitions by the seeds and adequate aeration for seeds to germinate quickly". River sand has good aeration and drainage, but low water holding capacity (Rivai et al. 2015; Milla et al. 2013). Similarly Agbogidi et al., (2007) observed that the significant higher germination percentage of $\mathrm{D}$. edulis seedlings sown in river sand could be attributed in part to the greater porosity when compared to the other media consequent upon 
the greater spaces for air and water, which are the basic conditions for seed germination. Although sharp sand is poor in nutrients, Isirimal et al. (2003) maintained that they are ideal for seed germination as the germinating embryos depend on stored nutrients within the seed for their initial growth and other metabolic activities.

This finding is similar to earlier reports by Awodola (2002), on Parkia biglobosa seeds who reported higher germination in seeds grown in river soils than in top soils. Similarly, Owonubi et al. (2005) recorded fairly good germination for Azadirachta indica seeds planted in river soils. The finding of this study is in contrast with the findings of Okunomo (2000; 2004), who reported a higher germination percentage in topsoil with D.edulis.

\subsection{Effect of Planting Media on Growth Variables of D. Edulis Seedlings}

The results on leaf area of $\mathrm{D}$. edulis implied that river sand medium is suitable to raise $\mathrm{D}$. edulis seedlings for the purpose of plantation establishment in the study area. This agrees with the findings of Okunlola (2016) who recorded highest result in river sand with A. muricata.

The result on the height growth of $\mathrm{D}$. edulis showed that the highest height was recorded by the composite mixture of river sand and sawdust. This result disagrees with the work Anber (2010) who obtained highest seedling height in topsoil with D. regia. It also disagrees with the work of Okunomo (2010) who obtained higher seedling height in poultry droppings than other treatments (topsoil, sharp sand, sawdust, clay soil, cow dung and pig manure) with P. bicolor. The result on seedlings diameter growth of D. edulis implied that, the best mean collar diameter (girth) was recorded in sawdust. There was no significant difference between river sand, sawdust and composite mixture of sawdust and river sand. The relatively slow growth recorded in topsoil medium is in contrast to the work of Agbogidi et al (2007) who recorded highest seedling performance in top soil with D. edulis. This could be attributed to the soil characteristics present which do not favor rapid growth of the species.

\section{CONCLUSION}

The finding of this study showed that the germination percentage and early growth rate of D. edulis was best recorded in river sand. This could be as a result of high porosity of river sand compared to topsoil and sawdust; the porosity of river sand allows imbibitions by the seeds and adequate aeration for seeds to germinate quickly. The relatively slow growth recorded in topsoil medium; this could be as a result of the soil characteristics (such as low porosity) which do not favor rapid growth of the species. Thus, it is recommended that river sand should be utilized as planting medium for raising D. edulis seedlings to ensure faster germination. The combination of river sand and sawdust can be an alternative for raising D. edulis seedlings especially in the study area.

\section{REFERENCES}

[1] Agbogidi, O. M. and Dolor, D. (2007): An Assessment of the Growth of Irvingiagabonensis (AubryLecomte Ex O`Rorte) Bail Seedlings as Influenced by Crude Oil Contamination of Soil. Asian Journal of Plant Sciences; 6 (10): 1287-1292.

[2] Agbogidi, O.M. and O.F. Eshegbeyi (2006): Performance of Dacryodesedulis (Don. G. Lam H.J.) seeds and seedlings in a crude oil contaminated soil; Journal of Sustainable Forestry, 22: 1-13.

[3] Akinnifesi, F.K.; Sileshi, G.; Ajayi O.C.; Chirwa, P.W.; Kwesiga, F.R. and Harawa, R. (2008): Contributions of agroforestry research anddevelopment to livelihood of smallholder farmers in Southern Africa: 2. Fruit, medicinal, fuelwood and fodder tree systems. Agriculture Journal 3:76-88.

[4] Albrecht A, Kandji S.T. (2003): Carbon sequestration in tropicalAgroforestry systems agriculture. AgrEcosyst Environ; 99:15-27.

[5] Aluko O.A.; Olanipekun T,O.; Olasoji J.O.; Abiola I.O.; Adeniyan O.N.; Olanipekun S.O.; Omenna E.C.; Kareem K.O. and Douglas A.I. (2014): effect of organic and inorganic fertilizer on the yield and nutrient composition of jute mallow; Global Journal of Agriculture Research 2 (3): 1-9; Published by European Centre for Research Training and Development UK (www.eajournals.org).

[6] Awono, A., O. Ndoye, K. Schreckenberg, H. Tabuna, F. Isseri and N. Temple, (2002): Production and marketing of safou (.Dacryodes edulis) in Cameroon and internationally: Market development issues. Forests Trees Livelihoods, 12: 125-147.

[7] Imoro, A-W.M.; Sackey I. and Abubakari, A-H. (2012): Preliminary Study on the Effects of Two Different Sources of Organic Manure on the Growth Performance of Moringaoleifera Seedlings; Journal of Biology, Agriculture and Healthcare; 2 (10): 147- 158.

[8] Isirimah, A.O., A.A. Dickson and C. Igwe (2003):Introductory Soil Chemistry and Biology.Osia Publishers Ltd. Diobu, Port Harcourt Nigeria, pp: 187.

[9] Leakey, R.R.B (1999): Potential for novel food products from Agro-forestry trees: A review. Food Chem, 66: 1-14. 
[10] Nwoboshi, L.C. (2000): The Nutrients Factor in Sustainable Forestry. University Press, Ibadan.

[11] Nyamukuru, A.J.,Tabuti, R. S. and Aduma, P. R. (2014): Propagationand seedling establishment of selected multipurpose woody species of Uganda, International Journal of Biodiversity Science, Ecosystem Services \& Management, 10(4):270-274.

[12] OkunlolaA. I. (2016): Evaluation of the Effect of Different Nursery Media on the Emergence and Growth of Three Tropical Tree Species. Global Journal of Science Frontier Research: Double Blind Peer Reviewed International Research Journal Publisher: Online ISSN:2249-4 626 and Print ISSN: 0975-5896.

[13] Okunomo, K., Oghenerhoro, E. O. and Ojiefo, I.M. (2004): Effect of soil type on the Germination and Seedling growth of dacryodesedulis Don G. Lam H. J) Journal of Sustainable Tropical Agricultural Research 12:46-50.

[14] Okunomo, K., Ogisi, D. O. and Bosah, B.O. (2009): Effect of growth media on Germination and Seedling growth of Perseaamericana (Mill). Journal of Food, Agriculture and Environment. 7 (1): 111-113.

[15] Owonubi, J.J., G.O. Otegbeye and C. Nwokedi (2005): Development of pre-germination investigation. Proceedings of the 30th Annual Conference of the Forestry Association of Nigeria, November 7-11, 2005, Kaduna State, Nigeria, pp: 497-505.

[16] Schreckenberg K, Degrande A, Mbosso C, Baboule ZB, Boyd C, Enyong L, Kanmegne J, Ngong C. (2002): The social and economic importance of Dacryodes edulis (G.Don) H.J. Lamin Southern Cameroon. Forests Trees Livelihoods; 12:15-40.

[17] Seibert, U. (2007): "Languages of Benué State"; Nigerian Languages; Department of Languages and Linguistics, University of Jos.

[18] William J. Asante, Kwame Ochire-Boadu and Baatuuwie N. B. (2012): Initial growth response of Moringa oleifera seedlings to different soil amendments. African Journal of Agricultural Research, 7(45): 60826086.

\section{APPENDIX}

Table2. Effects of Different Planting Media on the Mean number of leaves, Height and Girth of Dacryodesedulis Seedlings in University of Agriculture, Makurdi

\begin{tabular}{|c|c|c|c|c|c|c|}
\hline Variables & Sources of variation & $\begin{array}{l}\text { Sum of } \\
\text { Squares }\end{array}$ & df & Mean Square & $\mathbf{F}$ & Sig. \\
\hline \multirow[t]{3}{*}{ Leaf No } & Between Groups & 498.206 & 3 & 166.069 & 10.669 & .000 \\
\hline & Within Groups & 7409.442 & 476 & 15.566 & & \\
\hline & Total & 7907.648 & 479 & & & \\
\hline \multirow[t]{3}{*}{ Height } & Between Groups & 1991.886 & 3 & 663.962 & 15.251 & .000 \\
\hline & Within Groups & 20722.875 & 476 & 43.535 & & \\
\hline & Total & 22714.761 & 479 & & & \\
\hline \multirow[t]{3}{*}{ Girth } & Between Groups & .399 & 3 & .133 & 5.180 & .002 \\
\hline & Within Groups & 12.224 & 476 & .026 & & \\
\hline & Total & 12.623 & 479 & & & \\
\hline \multirow[t]{3}{*}{ Leaf area } & Between Groups & 2534.977 & 3 & 844.992 & 11.008 & .000 \\
\hline & Within Groups & 10746.979 & 140 & 76.764 & & \\
\hline & Total & 13281.957 & 143 & & & \\
\hline
\end{tabular}

Citation: J. Amonum et al., "Effect of Planting Media on the Germination and Early Growth of Dacryodes Edulis (G. Don) H. J. Lam", International Journal of Forestry and Horticulture (IJFH), vol. 5, no. 1, pp. 6-11, 2019. Available: DOI: http://dx.doi.org/10.20431/2454-9487.0501002

Copyright: (C) 2019 Authors. This is an open-access article distributed under the terms of the Creative Commons Attribution License, which permits unrestricted use, distribution, and reproduction in any medium, provided the original author and source are credited. 